\title{
The Discriminative Power of Inflammatory Markers in Patients with Mild-To-Moderate Acute Pancreatitis: Mean Platelet Volume, Neutrophil-Lymphocyte Ratio, Lymphocyte-Monocyte Ratio, and Neutrophil-Monocyte Product
}

\author{
(1) Ebru Unal Akoglu, ${ }^{1}$ (1) Serdar Özdemir, ${ }^{2}$ (1) Rohat Ak, ${ }^{3}$ (1) Tuba Cimilli Ozturk
}

'Department of Emergency Medicine, Fatih Sultan Mehmet Training and Research Hospital, İstanbul, Turkey

${ }^{2}$ Department of Emergency Medicine, Ümraniye Training and Research Hospital, İstanbul, Turkey

${ }^{3}$ Department of Emergency

Medicine, University of Health

Sciences, Kartal Dr. Lütfi Kırdar Training and Research Hospital, Istanbul, Turkey

Submitted: 30.09 .2020 Accepted: 11.02.2021

Correspondence: Ebru Unal Akoglu, Fatih Sultan Mehmet Eğitim ve Araştırma Hastanesi, Acil Tıp Kliniği İstanbul, Turkey

E-mail: eunalakoglu@gmail.com

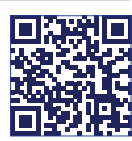

Keywords: Acute pancreatitis; inflammatory parameters; severity scoring. Attribution-NonCommercial 4.0 International License.

\section{ABSTRACT}

Objective: The exact parameters that differentiate mild acute pancreatitis (AP) from moderate AP are still unclear. The primary aim of this study was to evaluate the prognostic utility of recently used inflammatory parameters in AP patients.

\begin{abstract}
Methods: We retrospectively collected the level of inflammatory parameters of patients who were diagnosed with AP at the onset and remission of the disease. The inflammatory parameters - mean platelet volume (MPV), neutrophil-lymphocyte ratio (NLR), neutrophil-monocyte product (NMP), and platelet-lymphocyte ratio (PLR) - were derived from the electronic patient database. The day of the presentation to the emergency department (ED) was accepted as the day of the symptom onset, and the day when the patient declared to be pain free and started to take oral nutrition was accepted as the date of remission. We also calculated the clinical utility metrics such as positive and negative likelihood ratios at this threshold.
\end{abstract}

Results: A total of 217 AP patients were retrieved from the system, and the final study population consisted of 183 AP (84.3\%). According to revised Atlanta classification, 142 (77.6\%) patients were mild AP (MAP) and $4 \mathrm{I}$ (22.4\%) were moderate and severe AP (MSAP-SAP). Median neutrophil and lymphocyte counts, PLR, NLR, and NMP were all significantly higher, and lymphocyte-monocyte ratio was significantly lower in MAP group. At remission, the median MPV level was significantly higher $(p=0.0062)$, and median white blood cell $(W B C)$ level was significantly lower $(p<0.000 I)$. The same trend was observed in MAP group for both MPV and WBC, but not present for MPV in MSAP-SAP group.

Conclusion: We found that all inflammatory markers and ratios were significantly different between MAP and MSAP groups. Among those markers, NLR was the most powerful to discriminate between those groups. During AP from onset to remission, the changes in MPV had no benefit but the change in WBC was significant regardless of AP severity.

\section{INTRODUCTION}

Acute pancreatitis (AP) is the sudden inflammation of the pancreas due to activation of its enzymes. ${ }^{[l]}$ The incidence of the disease varies from 5 to $80 / 100.000$, and overall mortality ranges from $10 \%$ to $15 \%{ }^{[2]}$ In most cases, the course of the disease is mild and self-limiting. Approximately $20 \%$ of patients have a severe course with systemic complications, causing a high mortality rate ranging from
$29 \%$ to $43 \%{ }^{[3,4]}$ Characteristic abdominal pain and elevation of the plasma levels of pancreatic enzymes are vital points for the diagnosis of AP, despite a few reports regarding normal levels of enzymes in pancreatitis. ${ }^{[5,6]}$ Early detection of disease severity is crucial for a good outcome. Plasma levels of the pancreatic enzymes reflect the severity of AP poorly. ${ }^{[3]}$ For that reason, several biomarkers and a variety of scoring systems (Ranson criteria, ${ }^{[7]}$ Bedside index for severity in acute pancreatitis, ${ }^{[8]}$ and computed tomography 
severity index $[\mathrm{CTSI}]^{[0]}$ ) were introduced. ${ }^{[10]}$ Unfortunately, a variety of laboratory and imaging data are needed for the calculation of those scores. ${ }^{[1]}$ Therefore, more easily obtained parameters are continuously investigated for the prediction of AP severity. The moderately severe and severe AP (MSAP-SAP) patients are mostly admitted to the hospital because of the possibility of poor progression of the disease. Nevertheless, it is hard to determine the mild AP patients who need hospitalization.

An increase in white blood cell (WBC) count is the simplest indicator of acute inflammation in the peripheral blood and oldest marker to be studied in AP. Recently, markers derived from differential WBC counts, such as neutrophil-to-lymphocyte ratio (NLR), ${ }^{[12-14]}$ neutrophil-monocyte product (NMP), ${ }^{[15]}$ and the platelet-lymphocyte ratio (PLR), ${ }^{[16]}$ were introduced, and they were shown to have variable utilities in prognosis.

Mean platelet volume (MPV) is a measure of platelet size and can be obtained from the complete blood count (CBC) analysis. ${ }^{[10]}$ In literature, there are many studies in which MPV has been mentioned as an indicator of platelet function, especially in thrombotic and inflammatory conditions. [17-19] It is hypothesized that MPV reflects disease activity and inflammatory burden. The likelihood of adhesion and aggregation of large-sized platelets are more than small ones. ${ }^{[20]}$ Radiological imaging, biochemical markers, pathological analysis, and scoring systems are used to predict the severity and prognosis of AP. However, the role of platelets in the pathogenesis of AP and the utility of their size for the prediction of severity have not yet been clearly understood.

The primary aim of this study was to evaluate the predictive utility of CBC-derived inflammatory parameters in differentiating mild and MSAP patients.

\section{MATERIALS AND METHODS}

\section{Study design}

This was a retrospective study conducted at the Fatih Sultan Mehmet Education and Research Hospital emergency department with an annual patient load of 720.000. The cohort consisted of 217 patients with AP who presented to ED between January I, 20I3, and December 3I, 2014. The local ethics committee approved this study.

\section{Patient selection}

We cross-referenced all adult (age over 18) patients in Fatih Sultan Mehmet Education and Research Hospital, who had (International Classification of Diseases, $9^{\text {th }}$ revision clinical modification) diagnosis codes pertaining to AP in the Healthcare Operation System database of the hospital. The individual electronic medical records of the patients who were identified as AP were reviewed manually and the final diagnosis was determined.

The diagnosis of AP was confirmed by the presence of two of the three following criteria within the patients' electronic medical records: (I) Characteristic abdominal pain, (II) more than 3 times increase in serum pancreatic enzymes compared to the upper normal limit; and/or (III) typical findings in radiological imaging as defined by revised Atlanta classification for AP ${ }^{[21]}$ Mild AP (MAP) was defined as the absence of organ failure and local/systemic complications. MSAP was described as no evidence of persistent organ failure, but the presence of local or systemic complications and/or organ failure that resolved within $48 \mathrm{~h}$. SAP was defined as persistent organ failure over $48 \mathrm{~h}$.

\section{Exclusion criteria}

Patients who were diagnosed as traumatic or autoimmune pancreatitis were not included in the study. Only the first admission of the patients with recurrent pancreatitis was included. Patients with a history of malignancy, end-stage renal or liver disease, diabetes mellitus, platelet disorder, and any patients with documented/reported inflammatory diseases were excluded from the study. Patients with missing data or patients who had died due to a disease or complication of a disease other than pancreatitis (e.g., myocardial infarction and sepsis) were also excluded from the study.

Demographics, laboratory analysis, and outcome measures

Demographic and clinical characteristics of all the patients, including age, sex, medical history, radiologic imaging, and laboratory findings, were retrieved from Healthcare Information System at the onset and remission of the AP. The day when the patient was presented with abdominal pain was accepted as the time of onset. The day when the patient was pain free and started to take oral nutrition was recognized as the date of remission.

CBC parameters, including WBC count, MPV values (normal range: 6.0 and $10.0 \mathrm{fL}$ ), platelet count, lymphocyte count, monocyte count, neutrophil count, glucose, blood urea nitrogen, creatinine, aspartate aminotransferase, alanine aminotransferase, lactate dehydrogenase, amylase, and lipase, and mental status at the onset and remission were retrieved and recorded. Findings declared on the radiological imaging reports were recorded.

Data collection was performed by two emergency physicians (EPs) using a structured data abstraction form. Both EPs verified the completeness and accuracy of each form.

\section{Statistical analysis}

The data were presented with medians and interquartile range for continuous variables, and with counts and percentages for categorical variables. Pearson's $\chi^{2}$ or Fisher's exact tests were used for the comparison of categorical variables. Continuous variables were compared to the normal distribution with Kolmogorov-Smirnov test. Then, Student's t-test or the Mann-Whitney U-test was performed depending on their distribution. The Bonferroni method was used to adjust for multiple comparisons. The sensitivity, specificity, and positive (+LR) and negative likelihood ratios (-LR) were calculated using contingency 
tables. The accepted type I error was 5\%. All statistical analyses were performed using MedCalc Statistical Software version 18 (MedCalc Software bvba, Ostend, Belgium; http://www.medcalc.org; 2018).

\section{RESULTS}

A total of 217 AP patients were retrieved from the system, 34 were excluded for missing data, and the final study population consisted of 183 AP (84.3\%). According to revised Atlanta classification, 142 (77.6\%) patients were MAP, 39 (21.3\%) were MSAP, and 2 (1.1\%) were SAP. Both SAP patients died during the admission period.

Patients were grouped as MAP versus MSAP-SAP for convenience. MSAP-SAP patients were older $(p<0.000 \mathrm{I})$ with a male predominance (63.4\%). Median WBC, neutrophil and lymphocyte counts, PLR, NLR, and NMP were all significantly higher, and lymphocyte-monocyte ratio (LMR) was substantially lower in MSAP group. Demographics, laboratory values, and outcome measures of the study population are presented in Table I.

The comparison of median MPV and WBC levels at onset and remission is shown in Table 2. At remission, the median MPV level was significantly higher $(p=0.0062)$, and median WBC level was significantly lower $(p<0.0001)$. The same trend was observed for both MPV and WBC in MAP group (Table 2).

The prognostic utility of inflammatory markers; NLR, WBC, PLR, NMP, LMR, and MPV according to revised Atlanta severity classification is presented in Table 3.

\section{DISCUSSION}

$\mathrm{AP}$ is a disease of pancreatic inflammation, and this inflammation spreads with the severity of the disease process. In

Table I. Demographics and laboratory findings in patients with acute pancreatitis

\begin{tabular}{|c|c|c|c|c|}
\hline Variables & All patients $(n=183)$ & MAP $(n=142)$ & MSAP $(n=4 I)$ & $\mathbf{p}$ \\
\hline Age (years) & $58.0(47.0-72.0)$ & $53.0(45.0-65.0)$ & $77.0(70.0-83.0)$ & $<0.0001$ \\
\hline Male (\%) & 87 (47.5\%) & 61 (42.9\%) & $26(63.4 \%)$ & 0.0219 \\
\hline \multicolumn{5}{|l|}{ Onset } \\
\hline GCS & $15.0(15.0-15.0)$ & $15.0(\mid 5.0-15.0)$ & $15.0(15.0-15.0)$ & 1.0000 \\
\hline HR (bpm) & $80.0(75.0-90.0), n=182$ & $80.0(74.0-89.0)$ & $84.5(78.0-105.5), n=40$ & 0.0160 \\
\hline $\mathrm{RR}(/ \mathrm{min})$ & $14.0(13.0-15.0)$ & $14.0(13.0-15.0)$ & $14.0(\mid 3.0-15.0)$ & 0.3690 \\
\hline Temperature (C) & $36.3(36.0-36.8)$ & $36.2(36.0-36.8)$ & $36.4(36.0-36.9)$ & 0.2994 \\
\hline Glucose (mg/dl) & $133.0(113.0-163.0)$ & $130.5(|| \mid .0-158.0)$ & $14 \mid .0(12 \mid .8-178.0)$ & 0.0926 \\
\hline Amylase (U/L) & $973.0(408.5-2159.3)$ & $968.5(389.0-2270.0)$ & $1031.0(425.5-1626.8)$ & 0.3879 \\
\hline Lipase (U/L) & $632.0(500.0-2414.5)$ & $610(500.0-2522.0)$ & $654.0(500.0-2457.5)$ & 0.7487 \\
\hline AST (U/L) & $124.0(34.0-254.0), n=\mid 82$ & $|29.0(3 \mid .8-258.3), n=| 4 \mid$ & $91.0(47.0-215.8)$ & 0.8982 \\
\hline BUN (mg/dl) & $15.0(12.0-20.0)$ & $14.0(\mid 1.0-17.0)$ & $27.0(19.0-32.3)$ & $<0.0001$ \\
\hline LDH (U/L) & $262.5(193.0-380.0), n=174$ & $257.0(|89.3-38| .5), n=135$ & $283.0(207.5-376.3), n=39$ & 0.2846 \\
\hline Platelet count $\left(\times 10^{9} / \mathrm{L}\right)$ & $240.0(205.0-285.0)$ & $238.0(205.0-283.0)$ & $254.0(208.3-307.0)$ & 0.3600 \\
\hline MPV (fL) & $7.9(7.3-8.7)$ & $8.0(7.4-8.9)$ & $7.8(7.2-8.4)$ & 0.0620 \\
\hline CRP (mg/L) & $8.0(2.5-12.0), n=157$ & $6.0(1.7-11.0), n=118$ & $11.0(7.3-17.8), n=39$ & 0.0013 \\
\hline WBC (x109/L) & $11.7(9.4-15.6)$ & $10.9(9.2-14.2)$ & $15.6(11.6-19.6)$ & $<0.0001$ \\
\hline Neutrophile count $\left(x \mid 0^{9} / \mathrm{L}\right)$ & $9.0(6.2-12.5)$ & $8.0(5.8-10.8)$ & $13.0(9.6-16.4)$ & $<0.0001$ \\
\hline Lymphocyte count (x109/L) & $2.0(1.4-2.7)$ & $2.2(1.6-2.8)$ & $1.5(1.0-2.1)$ & 0.0011 \\
\hline Monocyte count (x109/L) & $0.7(0.4-0.8)$ & $0.7(0.5-0.8)$ & $0.7(0.4-0.9)$ & 0.8983 \\
\hline PLR & $123.2(86.0-194.8)$ & II 5.1 (84.4-I70.0) & $160.0(101.0-280.5)$ & 0.0014 \\
\hline LMR & $3.39(2.27-4.95), n=179$ & $3.67(2.50-4.95), n=139$ & $2.61(1.69-4.75), n=40$ & 0.0245 \\
\hline NLR & $4.84(2.63-7.97)$ & $4.04(2.42-6.05)$ & $8.40(5.52-12.91)$ & $<0.0001$ \\
\hline $\operatorname{NMP}\left(/ / 0^{6}\right)$ & $5.16(3.21-9.20)$ & $4.71(3.18-7.80)$ & $7.0(4.65-12.93)$ & 0.0066 \\
\hline \multicolumn{5}{|l|}{ Discharge } \\
\hline DoA (days) & $4.0(3.0-6.0), n=182$ & $3.0(2.0-5.0)$ & $5.0(3.5-10.0), n=40$ & 0.0001 \\
\hline MPV (fL) & $8.1(7.3-9.4), n=179$ & $8.3(7.3-9.4), n=138$ & $7.7(7.2-8.6)$ & 0.1029 \\
\hline $\mathrm{CRP}(\mathrm{mg} / \mathrm{L})$ & $7.0(3.0-11.0), n=166$ & $6.0(2.4-10.0), n=127$ & $10.0(5.9-14.0), n=39$ & 0.0026 \\
\hline WBC (x109/L) & $8.4(6.5-10.3), n=179$ & $8.3(6.5-10.0), n=138$ & $9.3(6.9-12.9)$ & 0.0774 \\
\hline Mortality (\%) & $2(1.1 \%)$ & $0(0 \%)$ & $2(4.9 \%)$ & 0.0492 \\
\hline
\end{tabular}

Continuous variables are presented as median (IQR). P values with statistically significant differences between groups are shown in bold. All comparisons between subgroups were tested with Mann-Whitney U except sex and mortality, where Fischer's exact test was used. GCS: Glasgow Coma Score; HR: Heart Rate; RR: Respiratory Rate; WBC: White blood cell count; CRP: C-reactive protein; PLR: Platelet-lymphocyte ratio; LMR: Lymphocyte-monocyte ratio; NLR: Neutrophil-lymphocyte ratio; NMP: Neutrophil-monocyte product; MAP: Mild acute pancreatitis; MSAP: Moderate and severe acute pancreatitis; DoA: Duration of admission. 
Table 2. Comparison of MPV and WBC levels at onset and remission of acute pancreatitis patients

\begin{tabular}{|c|c|c|c|}
\hline Variables & All patients & MAP & MSAP \\
\hline MPV (fL), Onset & $7.9(7.3-8.7), n=183$ & $8.0(7.4-8.9), n=142$ & $7.8(7.2-8.4), n=4 \mid$ \\
\hline MPV (fL), Discharge & $8.1(7.3-9.4), n=179$ & $8.3(7.3-9.4), n=138$ & $7.7(7.2-8.6), n=4 I$ \\
\hline $\mathrm{p}$-value & $0.0062, n=179$ & $0.0355, n=138$ & $0.055 \mathrm{I}, \mathrm{n}=4 \mathrm{I}$ \\
\hline WBC (x109/L), Onset & $11.7(9.4-15.6), n=183$ & $10.9(9.2-14.2), n=142$ & $15.6(\mid 1.6-19.6), n=4 \mid$ \\
\hline WBC (x|09/L), Discharge & $8.4(6.6-10.3), n=179$ & $8.3(6.5-10.0), n=138$ & $9.3(6.9-12.9), n=4 \mid$ \\
\hline $\mathrm{p}$-value & $<0.0001, n=179$ & $<0.0001, n=138$ & $<0.0001, n=41$ \\
\hline
\end{tabular}

Comparisons were made by Wilcoxon rank sum test for paired samples. Statistically significant changes were shown as bold. MPV: Mean platelet volume; WBC: White blood cell count; MAP: Mild acute pancreatitis; MSAP: Moderate and severe acute pancreatitis.

Table 3. Prognostic utility of inflammatory markers according to revised Atlanta Severity Classification

\begin{tabular}{|c|c|c|c|c|c|c|c|}
\hline & AUC $(95 \% \mathrm{Cl})$ & $\mathbf{p}$ & Threshold & Sensitivity & Specificity & +LR & $-L R$ \\
\hline NLR & $0.788(0.72 \mathrm{I}-0.844)$ & $<0.0001$ & 5.11 & $1.2)$ & $67.6(59.2$ & $2.48(1.9-3.3)$ & $0.29(0.2-0.5)$ \\
\hline WBC (x109/L) & $0.713(0.642-0.777)$ & $<0.0001$ & 14 & 63.4 (46.9-77.9) & 73.9 (65.9-80.9) & $2.43(1.7-3.5)$ & $0.49(0.3-0.7)$ \\
\hline PLR & $0.664(0.590-0.732)$ & 0.0007 & 132.7 & $65.9(49.4-79.9)$ & $64.8(56.3-72.6)$ & $1.87(1.4-2.4)$ & $0.53(0.3-0.8)$ \\
\hline $\operatorname{NMP}\left(/ / 0^{6}\right)$ & $0.639(0.565-0.709)$ & 0.0086 & 4.77 & $75.6(59.7-87.6)$ & $51.4(42.9-59.9)$ & $1.56(1.2-2.0)$ & $0.47(0.3-0.8)$ \\
\hline LMR & $0.617(0.54 I-0.688)$ & 0.0402 & 2.25 & 47.5 (31.5-63.9) & 81.3 (73.8-87.4) & $2.54(1.6-4.1)$ & $0.65(0.5-0.9)$ \\
\hline MPV (fL) & $0.596(0.52 I-0.668)$ & 0.0412 & 8.1 & $73.2(57.1-85.8)$ & $45.1(36.7-53.6)$ & $1.33(1.1-1.7)$ & $0.60(0.3-1.0)$ \\
\hline
\end{tabular}

AUC: Area Under Curve; NLR: Neutrophil-lymphocyte ratio; WBC: White blood cell count; CRP: C-reactive protein; PLR: Platelet-lymhocyte ratio; LMR: Lymphocyte-monocyte ratio; NMP: Neutrophile-monocyte product; MPV: Mean platelet volume.

this study, we investigated and compared the prognostic utility of WBC, NLR, PLR, NMP, LMR, and MPV in AP. All inflammatory markers were statistically significantly different between MAP and MSAP-SAP groups. Among those, NLR was the best to discriminate between MAP and MSAP-SAP with an accuracy higher than WBC. We also investigated the change in MPV and WBC during AP from onset to remission and found that the shift in MPV was clinically insignificant regardless of AP severity. On the contrary, WBC was a valuable marker in the clinical course of AP patients.

The rationale behinds the use of platelet, neutrophil, monocyte, and lymphocyte counts and their various ratios/products lie in the mechanisms related to systemic inflammation. However, the number of comparative studies on their prognostic utility is negligible. In AP, tissue destruction occurs through the activation of cytokines, proteolytic enzymes, and radicals. ${ }^{[14]}$ Neutrophils, leukocytes, and monocytes are activated at different levels to fight with inflammation. Neutrophils attack necrotic tissue and help the development of systemic complications. Thus, their increased levels are linked to worse prognosis, and depletion of neutrophils was shown to be related with improved prognosis. ${ }^{[22]}$ Lymphopenia is another finding in severe pancreatitis ${ }^{[4,23-25]}$ and was linked to apoptotic cell death. ${ }^{[26]}$ Monocytes recruit other inflammatory cells into the pancreas, ${ }^{[14]}$ and their depletion was shown to have a protective effect. Therefore, the opposite effects of neutrophil and monocytes with lymphocytes led to the evolution of new parameters such as NLR, LMR, and NMP.
We found that the NLR (0.79) has the highest prognostic accuracy compared to other inflammatory parameters and ratios. This finding is similar to the previous research. ${ }^{[14]}$ Despite the theoretical utility, the accuracy of NMP (0.64) and LMR (0.62) was moderate and far from being clinically useful. In a recent retrospective cohort study conducted by Li et al. ${ }^{[14]}$ in China, they compared the utility of red cell distribution width, NLR, CRP, LMR, and prognostic nutritional index and reported NLR as the most powerful marker for the prediction of survival in AP patients with an AUC of 0.82 . Those findings need to be verified in other races, as well.

MPV is another marker decreasing with the severity of inflammation. ${ }^{[27]}$ Although several studies have shown that larger MPV values and severities of inflammatory processes are highly correlated, a survey among patients with acute familial Mediterranean fever reported lower MPV values compared to patients with inactive disease. ${ }^{[28]}$ Gasparyan et al. ${ }^{[18]}$ interpreted this difference by hypothesizing that small-sized platelets are mostly observed in highgrade inflammatory conditions, and the disease remission is characterized by large platelets.

Several cytokines play an essential role in the pathogenesis of AP and may affect MPV. However, it is unclear if MPV increases or decreases with inflammation. Mimidis et al., ${ }^{[29]}$ in a study of 54 AP patients, reported that MPV levels were decreased at the onset of AP. Lei et al.,"27] in a study of 117 AP patients, found that serum MPV levels were significantly lower in AP patients when compared to control group. However, in contrast, Akbal et al. ${ }^{[30]}$ have 
reported an increase in MPV levels in the early phase of AP compared with controls, and MPV levels were still elevated in remission. No difference was found between the onset $(8.6 \mathrm{fL})$ and remission $(8.5 \mathrm{fL}) \mathrm{MPV}$ values, and both were higher compared to controls. They suggested that the increase in MPV levels may reflect the thrombotic process in AP, not inflammation. The relationship between the level of MPV and AP severity is also uncertain. Mimidis et al. ${ }^{[29]}$ used APACHE II score to predict the severity of $A P$, and they found a good correlation between the level of MPV and severity. However, according to a study by Beyazit et al.,. ${ }^{[1]}$ no correlation between CTSI and MPV level is present. Lei et al. ${ }^{[27]}$ used the modified Glasgow prognostic score to predict the severity of AP, and they found the MPV levels in patients with persistent organ failure after admission to be lower. The accuracy of MPV in our study was also low (0.60). PLR performed slightly better compared to MPV with an accuracy of 0.66 , but both parameters were far from being clinically useful.

In this study, we evaluated several inexpensive and readily available markers. We confirmed the findings of a recent study of a Chinese cohort, on a Mediterranean cohort. However, the retrospective nature, one-centered design, and percentage of patients excluded due to missing data (15.7\%) are the main limitations of our study. Prospective studies in larger cohorts are needed to support our findings.

\section{CONCLUSION}

We found that all inflammatory markers and ratios were significantly different between mild and moderate-severe AP groups. Among those markers, NLR was the most powerful to discriminate between those groups. During AP from onset to remission, the changes in MPV were useless, but the difference in WBC was significant regardless of AP severity. WBC and NLR are cheap, quick, and helpful parameters in the assessment of disease activity, especially in the ED.

\section{Acknowledgments}

We would like to thank Professor Haldun Akoglu for his valuable support and assistance with the statistics used in this research work.

Ethics Committee Approval

This study approved by the İstanbul Fatih Sultan Mehmet Training and Research Hospital Ethics Committee (Date: 27.01.2015, Decision No: 2015/I).

Informed Consent

Retrospective study.

Peer-review

Internally peer-reviewed.

Authorship Contributions

Concept: S.Ö., R.A., E.U.A., T.C.O.; Design: S.Ö., R.A., E.U.A., T.C.O.; Supervision: S.Ö., R.A., E.U.A., T.C.O.;
Data: S.Ö., R.A., E.U.A., T.C.O.; Analysis: S.Ö., R.A., E.U.A., T.C.O.; Literature search: E.U.A., T.C.O.; Writing: E.U.A.; Critical revision: T.C.O.

Conflict of Interest

None declared.

\section{REFERENCES}

1. Cruz-Santamaría DM, Taxonera C, Giner M. Update on pathogenesis and clinical management of acute pancreatitis. World J Gastrointest Pathophysiol 2012;3:60-70.

2. Yousaf M, McCallion $\mathrm{K}$, Diamond T. Management of severe acute pancreatitis. Br J Surg 2003;90:407-20.

3. Karpavicius A, Dambrauskas Z, Sileikis A, Vitkus D, Strupas K. Value of adipokines in predicting the severity of acute pancreatitis: Comprehensive review. World J Gastroenterol 2012;18:6620-7.

4. Beduschi MG, Mello AL, Von-Mühlen B, Franzon O. The PANC 3 score predicting severity of acute pancreatitis. Arq Bras Cir Dig 2016;29:5-8.

5. Limon O, Sahin E, Kantar FU, Oray D, Ugurhan AA. A rare entity in ED: Normal lipase level in acute pancreatitis. Turk J Emerg Med 2016;16:32-4.

6. Matull WR, Pereira SP, O'Donohue JW. Biochemical markers of acute pancreatitis. J Clin Pathol 2006;59:340-4.

7. Ranson JH, Rifkind KM, Roses DF, Fink SD, Eng K, Spencer FC. Prognostic signs and the role of operative management in acute pancreatitis. Surg Gynecol Obstet 1974;139:69-81.

8. Wu BU, Johannes RS, Sun X, Tabak Y, Conwell DL, Banks PA. The early prediction of mortality in acute pancreatitis: A large population-based study. Gut 2008;57:1698-703.

9. Balthazar EJ, Robinson DL, Megibow AJ, Ranson JH. Acute pancreatitis: Value of CT in establishing prognosis. Radiology 1990;174:331-6.

10. Beyazit Y, Sayilir A, Torun S, Suvak B, Yesil Y, Purnak T, et al. Mean platelet volume as an indicator of disease severity in patients with acute pancreatitis. Clin Res Hepatol Gastroenterol 2012;36:162-8.

11. Chen L, Lu G, Zhou Q, Zhan Q. Evaluation of the BISAP score in predicting severity and prognoses of acute pancreatitis in Chinese patients. Int Surg 2013;98:6-12.

12. Jeon TJ, Park JY. Clinical significance of the neutrophil-lymphocyte ratio as an early predictive marker for adverse outcomes in patients with acute pancreatitis. World J Gastroenterol 2017;23:3883-9.

13. Han C, Zeng J, Lin R, Liu J, Qian W, Ding Z, et al. The utility of neutrophil to lymphocyte ratio and fluid sequestration as an early predictor of severe acute pancreatitis. Sci Rep 2017;7:10704.

14. Li Y, Zhao Y, Feng L, Guo R. Comparison of the prognostic values of inflammation markers in patients with acute pancreatitis: A retrospective cohort study. BMJ Open 2017;7:e013206.

15. Liu J, Bai Y, Aziguli A, Zhang YL. Value of neutrophil-monocyte product combined with serum creatinine in assessing the severity of acute pancreatitis. Nan Fang Yi Ke Da Xue Xue Bao 2017;37:12703.

16. İlhan M, İlhan G, Gök AF, Bademler S, Atmaca FV, Ertekin C. Evaluation of neutrophil-lymphocyte ratio, platelet-lymphocyte ratio and red blood cell distribution width-platelet ratio as early predictor of acute pancreatitis in pregnancy. J Matern Fetal Neonatal Med 2016;29:1476-80.

17. Ekber Karabulut A, Çevik Y, Emektar E, Çorbacioğlu ŞK, Dagar S, Yardim O. Analysis of mean platelet volume and red blood cell distribution width in recurrent epistaxis. Turk J Emerg Med 2018;18:6770 . 
18. Gasparyan AY, Ayvazyan L, Mikhailidis DP, Kitas GD. Mean platelet volume: A link between thrombosis and inflammation? Curr Pharm Des 2011;17:47-58.

19. Kucuk E, Kucuk I. Mean platelet volume is reduced in acute appendicitis. Turk J Emerg Med 2015;15:23-7.

20. Park Y, Schoene N, Harris W. Mean platelet volume as an indicator of platelet activation: Methodological issues. Platelets 2002;13:301-6.

21. Tenner S, Baillie J, DeWitt J, Vege SS, American College of Gastroenterology. American college of gastroenterology guideline: Management of acute pancreatitis. Am J Gastroenterol 2013;108:1400-15, 1416.

22. Xue J, Sharma V, Habtezion A. Immune cells and immune-based therapy in pancreatitis. Immunol Res 2014;58:378-86.

23. Zahorec R. Ratio of neutrophil to lymphocyte counts-rapid and simple parameter of systemic inflammation and stress in critically ill. Bratisl Lek Listy 2001;102:5-14.

24. de Jager CP, van Wijk PT, Mathoera RB, de Jongh-Leuvenink J, van der Poll T, Wever PC. Lymphocytopenia and neutrophil-lymphocyte count ratio predict bacteremia better than conventional infection markers in an emergency care unit. Crit Care 2010;14:R192.

25. Le Tulzo Y, Pangault C, Gacouin A, Guilloux V, Tribut O, Amiot L, et al. Early circulating lymphocyte apoptosis in human septic shock is associated with poor outcome. Shock 2002;18:487-94.

26. Takeyama Y, Takas K, Ueda T, Hori Y, Goshima M, Kuroda Y. Peripheral lymphocyte reduction in severe acute pancreatitis is caused by apoptotic cell death. J Gastrointest Surg 2000;4:379-87.

27. Lei J-J, Zhou L, Liu Q, Xiong C, Xu CF. Can mean platelet volume play a role in evaluating the severity of acute pancreatitis? World J Gastroenterol 2017;23:2404-13.

28. Makay B, Türkyilmaz Z, Unsal E. Mean platelet volume in children with familial Mediterranean fever. Clin Rheumatol 2009;28:975-8.

29. Mimidis K, Papadopoulos V, Kotsianidis J, Filippou D, Spanoudakis E, Bourikas G, et al. Alterations of platelet function, number and indexes during acute pancreatitis. Pancreatology 2004;4:22-7.

30. Akbal E, Demirci S, Koçak E, Köklü S, Başar O, Tuna Y. Alterations of platelet function and coagulation parameters during acute pancreatitis. Blood Coagul Fibrinolysis 2013;24:243-6.

\section{Hafif ile Orta Şiddetli Akut Pankreatit Hastalarında Enflamatuvar Belirteçlerin Ayırt Ettirici Gücü: Ortalama Trombosit Hacmi, Nötrofil-Lenfosit Oranı, Lenfosit-Monosit Oranı, Nötrofil-Monosit Oranı}

Amaç: Hafif akut pankreatiti (AP) orta düzey AP'den ayıran kesin parametreler hala belirsizdir. Bu çalışmanın birincil amacı, hafif ila orta-ağır AP hastalarında enflamatuvar belirteçlerinin ayırt ettirici gücünü değerlendirmektir.

Gereç ve Yöntem: AP tanısı alan hastaların klinik bilgileri ve hastalık başı ile remisyon anındaki enflamatuvar belirteç düzeyleri geriye dönük tek merkezli olarak toplandı. Enflamatuvar parametreler - Ortalama trombosit hacmi (MPV), nötrofil-lenfosit oranı (NLR), nötrofil-monosit ürünü (NMP), trombosit-lenfosit oranı (PLR) - elektronik veritabanından elde edildi. Acil servise başvuru günü belirti başlangıcı olarak kabul edildi ve hastanın ağrısız olduğu ve oral beslenmeye başladığı gün remisyon tarihi olarak kabul edildi. Hasta gruplarının klinik değerlik ölçütleri (duyarlılık, özgüllük, pozitif ve negatif olabilirlik olasılıkları) hesaplandı.

Bulgular: Toplam 217 AP hastası belirlendi, 34’ü (\%।5.7) veri eksiği nedeniyle dışlandı ve çalışma popülasyonu 183 AP hastasından (\%84.3) oluştu. Gözden geçirilmiş Atlanta Sınılamasına göre, 142 (\%77.6) hasta hafif AP (MAP) ve 39 (\%21.3) hasta orta-ağır AP (MSAP) idi. MAP grubunda ortanca nötrofil ve lenfosit sayıları, PLR, NLR, NMP, anlamlı olarak yüksek, LMR ise istatistiksel olarak anlamlı düzeyde düşük olarak belirlendi. Remisyon anında, ortanca MPV düzeyi anlamlı olarak daha yüksek iken $(p=0.0062)$ ortanca beyaz küre sayısı $(W B C)$ anlamlı derecede daha düşüktü $(p<0.000 I)$. Aynı eğilim, MPV ve WBC için de MAP grubunda gözlendi, ancak MSAP-SAP grubunda MPV için mevcut değildi.

Sonuç: Tüm enflamatuvar belirteçlerin ve oranların hafif ve orta-şiddetli AP grupları arasında anlamlı derecede farklı olduğunu bulduk. NLR gruplar arasında ayrım yapma yönünden en güçlü belirteçti. Başlangıçtan remisyona kadar, MPV değişimi anlamlı değilken, WBC'de değişimi, AP ciddiyetine bakılmaksızın, anlamlı ve önemliydi.

Anahtar Sözcükler: Akut pankreatit; enflamatuvar parametreler; skorlama sistemleri. 